\title{
Milksolids production from different combinations of perennial ryegrass and white clover cultivars: II Milksolids production and farm profitability
}

\author{
S.L. WOODWARD ${ }^{1}$, K.A. MACDONALD ${ }^{1}$, W.A. CARTER ${ }^{1}$, J.P.J. EERENS ${ }^{2}$ and J.R. CRUSH ${ }^{2}$ \\ ${ }^{1}$ Dexcel, Private Bag 3221, Hamilton \\ ${ }^{2}$ AgResearch, Private Bag 3123, Hamilton \\ sharon.woodward@dexcel.co.nz
}

\begin{abstract}
$1999 / 2000$ and $2000 / 2001$ were the first two complete seasons of a replicated farm systems trial designed to measure the effects on whole farm profitability (Economic Farm Surplus (EFS) of mixtures of ryegrasses and white clovers released on to the market recently, or at least 15 years ago, and rotationally grazed by dairy cows. All the pastures were sown in late autumn 1998. There were four treatments with all combinations of $1980 \mathrm{~s}$ (80R), and late 1990s (98R) ryegrasses, and 1960s (60C)and late 1990s (98C) white clovers, each replicated 3.0 times in a randomised block design giving twelve 4-ha, self-contained farmlets stocked with three Friesian cows/ha. Milksolids production was unaffected by either ryegrass or clover cultivar age, but there was a significant ryegrass $\mathrm{x}$ clover cultivar interaction reflected as higher milksolids production on the $80 \mathrm{R} / 98 \mathrm{C}$ treatment than the 98R/98C treatment in 1999/2000. This was a result of a higher clover content in the $80 \mathrm{R} / 98 \mathrm{C}$ pastures compared with other treatments. Although the difference in clover content was still present in $2000 / 2001$, the wetter summer-autumn meant the ryegrass maintained a higher nutritive value than in the previous season under dry conditions, so clover content did not affect milksolids production in $2000 / 2001$. There were no main treatment effects on EFS in either season, but there was a significant ryegrass x clover interaction in 1999/2000 shown as a higher EFS on the $80 \mathrm{R} / 98 \mathrm{C}$ treatment than on the $98 \mathrm{R} / 98 \mathrm{C}$ treatment.
\end{abstract}

Keywords: cultivars, dairying, Economic Farm Surplus, milksolids, perennial ryegrass, white clover

\section{Introduction}

Research on perennial ryegrass and white clover pastures in New Zealand since the 1930s has not provided measurement of increased milksolids (MS) production or dairy farm profitability from new (modern) cultivars. Results of dairy beef production trials in the Manawatu, which demonstrated higher animal production from pastures sown with new cultivars (Cosgrove \& Brougham 1988), were confounded because the old pasture controls were not ploughed and resown. McCallum \& Thomson (1994) measured performance of dairy cows grazing either old (Yatsyn 1) or new (Embassy, Vedette) ryegrass cultivar pastures during several short-term trials. They concluded that ryegrass cultivar had little effect on milksolids production, although the trial design did not account for differences in silage grown between cultivars. Some trials have demonstrated herbage production differences between clover cultivars under dairy grazing (Moloney et al. 1988), but milksolids production was not measured. Small plot trials under rotational dairy grazing in the Waikato region have shown only small differences in herbage production between old and new ryegrass (Thom et al. 1998) and white clover cultivars (Woodward \& Caradus 2000). However, the ultimate test of cultivars should be their performance in realistic production systems where the effects of any differences in agronomic characteristics, and resultant animal production, can be monitored (Laidlaw \& Reed 1993). Laidlaw \& Reed (1993) point out, however, that a major difficulty of systems trials is that inadequate control and management can result in the interaction between management and herbage production either masking or enhancing any actual differences which may exist between cultivars.

This paper is a progress report of results from the first two complete seasons (1999/00 and 2000/01) of a farm systems trial designed to evaluate the effects of perennial ryegrass and white clover breeding programmes on whole farm profitability (Economic Farm Surplus; EFS). The trial compared milksolids production, and EFS from farmlets based on combinations of recently released and older perennial ryegrass and white clover cultivars. Eerens et al. (2001) report on pasture aspects of the trial in the accompanying paper.

\section{Methods}

\section{Trial design}

The trial occupies 48 ha at the Dexcel (formerly Dairying Research Corporation Limited) Scott Farm 
near Hamilton. There are four pasture treatments consisting of mixtures representative of recently released and older cultivars (Table 1). Each treatment is replicated three times giving twelve, 4-ha farmlets.

Table 1 Treatments, and the perennial ryegrass and white clover cultivars used in a dairy farm systems trial measuring milksolids production and farm profitability from different pasture mixtures in the Waikato. Ryegrasses were representative of those available in the 1980s and 1998. White clovers were representative of those available in the 1960 s and 1998.

\begin{tabular}{ll}
\hline Treatment name & \multicolumn{1}{c}{ Description } \\
\hline 80R60C & 1980s ryegrass plus 1960s white clover \\
98R60C & 1998 ryegrass plus 1960s white clover \\
80R98C & 1980s ryegrass plus 1998 white clover \\
98R98C & 1998 ryegrass plus 1998 white clover \\
& \multicolumn{1}{c}{ Cultivars used } \\
1980s ryegrass & Yatsyn 1, Grasslands Nui, Ellett \\
1998 ryegrass & Bronsyn, Aries HD, Grasslands Samson \\
1960s clover & Grasslands Pitau, Grasslands Huia \\
1998 clover & Grasslands Sustain, Grasslands Challenge \\
\hline
\end{tabular}

\section{Pasture establishment}

All pastures were established in autumn 1998 after existing pastures had been sprayed with Roundup ${ }^{\mathrm{TM}}$, cultivated, and fallowed over summer. Sowing rate (bare seed) was $18 \mathrm{~kg} / \mathrm{ha}$ total ryegrass and $3 \mathrm{~kg} / \mathrm{ha}$ total white clover. Further establishment details are presented in Eerens et al. (2001). Treatments were rotationally grazed by separate herds from midSeptember 1998 to May 1999 to ensure that average total herbage dry matter (DM) was similar across all farmlets for the start of the 1999/2000 season.

\section{Cows}

All farmlets were stocked with 3.0 multiparous Friesian cows/ha and were rotationally grazed. At the start of the 1999/2000 season, farmlets were balanced for cow age, expected calving date, breeding worth, body condition score (CS), liveweight and previous milksolids production.

\section{Management}

The use of written decision rules which have been developed from previous farm systems trials at Dexcel (Macdonald \& Penno 1998) means that management decisions, which are typical of management on commercial, pastoral-based dairy farms, can be made objectively for each individual farmlet based on conditions on that farmlet, and without compromising expression of any treatment differences. These rules determine management of the grazing rotation, conservation and feeding of pasture silage, setting of cow condition score and liveweight targets, drying- off of cows, and use of bought-in maize silage supplement and/or grazing-off. Maintenance (phosphorus and potassium) and nitrogen (maximum of $100 \mathrm{~kg} \mathrm{~N} / \mathrm{ha} / \mathrm{y}$ ) fertiliser application, and the replacement heifer rate $(25 \%)$, were the same for all farmlets. Further details are provided by Eerens et al. (2001).

\section{Measurements}

A description of pasture measurements (pasture growth, herbage accumulation, pasture botanical composition, tiller density and clover growing point density, nitrogen fixation, and endophyte infection level) and results are presented in the Eerens et al. (2001) paper.

Total herbage mass ( $\mathrm{kg} \mathrm{DM} / \mathrm{ha})$ was estimated weekly in each paddock by calibrated visual assessment. These data were used primarily to optimise farmlet management decisions, and also to provide pasture growth rate and herbage accumulation data as described by Eerens et al. (2001).

Individual cow milk yields and milk composition were measured on 1 day per week throughout lactation. Milksolids production is a measure of milk fat yield plus milk protein yield. Individual cow body condition score and liveweight were measured fortnightly throughout the season.

EFS is a measure of the profitability of a dairy farm enterprise and is widely used as an indicator of economic trends within the industry (Penno et al. 1996). EFS was calculated according to Livestock Improvement Corporation (LIC) guidelines (see LIC Farm Facts 7-3). Farm income and expenses were calculated on a per hectare basis taking account of any differences in production, inputs (e.g., bought-in silage) and management on different farmlets. Where income and expenses were measured on a per cow basis, this was converted to per hectare using the current stocking rate. Costs of inputs and expenses were based on data from a current economic survey of New Zealand dairy farms (Dexcel Limited 2000) and the milksolids payout used was $\$ 4.00 / \mathrm{kg}$ MS.

All cow and EFS data were averaged on a farmlet basis and were analysed as a factorial, randomised block design using Genstat 5.

\section{Results and discussion}

\section{Milksolids production}

Total milksolids production per hectare for the 1999/ 2000 season ranged from $811 \mathrm{~kg} \mathrm{MS} / \mathrm{ha} / \mathrm{y}$ on one of the $98 \mathrm{R} / 98 \mathrm{C}$ farmlets to $1033 \mathrm{~kg} \mathrm{MS} / \mathrm{ha} / \mathrm{y}$ on one of the $80 \mathrm{R} / 98 \mathrm{C}$ farmlets. Production in the $2000 / 2001$ season was slightly higher with ranging from $937 \mathrm{~kg}$ $\mathrm{MS} / \mathrm{ha} / \mathrm{y}$ on one of the $98 \mathrm{R} / 98 \mathrm{C}$ farmlets, to $1129 \mathrm{~kg}$ 
$\mathrm{MS} / \mathrm{ha} / \mathrm{y}$ on one of the $80 \mathrm{R} / 98 \mathrm{C}$ farmlets. The higher milksolids production on all farmlets in the second season was due largely to the higher total dry matter production resulting from more rain during summerautumn (Eerens et al. 2001). Production levels on all farmlets from both seasons were above the Hamilton region's average for commercial dairy farms of $744 \mathrm{~kg}$ MS/ha/y (1992/1993 to 1999/2000) and the national average of $709 \mathrm{~kg} \mathrm{MS} / \mathrm{ha} / \mathrm{y}$ (Livestock Improvement 2000).

There were no significant effects of ryegrass or clover type on total milksolids production per cow or per hectare in either season. There was however, a ryegrass $\mathrm{x}$ clover interaction $(\mathrm{P}<0.10)$ in the 1999/ 2000 season, evidenced as higher production on the $80 \mathrm{R} / 98 \mathrm{C}$ treatment than on the $98 \mathrm{R} / 98 \mathrm{C}$ treatment (Table 2). The $80 \mathrm{R} / 60 \mathrm{C}$ and $98 \mathrm{R} / 60 \mathrm{C}$ treatments were intermediate and not significantly different from the $80 \mathrm{R} / 98 \mathrm{C}$ treatment. This trend was apparent only after

Table 2 1999/2000 season milk production, milk composition, cow liveweight and condition score (CS) at drying off, and Economic Farm Surplus (EFS; calculated assuming a payout of $\$ 4.00 / \mathrm{kg} \mathrm{MS}$ ) of the perennial ryegrass-white clover treatments. Figures are the means of the three replicate farmlets.

\begin{tabular}{lcccccc}
\hline Ryegrass-white clover & 80R60C & 98R60C & 80R98C & 98R98C & SED & 1 \\
\hline Days in milk (DIM) & 223 & 225 & 226 & 219 & 4 & n.s. \\
Milk (kg/cow) & 3945 & 3965 & 4205 & 3792 & 147 & $\dagger$ \\
Milk fat concentration (\%) & 4.42 & 4.43 & 4.27 & 4.33 & 0.11 & n.s. \\
Milk protein concentration (\%) & 3.40 & 3.40 & 3.38 & 3.36 & 0.05 & n.s. \\
Milksolids (kg/cow) & 308 & 310 & 321 & 292 & 10 & $\dagger$ \\
Milksolids (kg/ha) & 925 & 930 & 964 & 875 & 30 & $\dagger$ \\
Milksolids per DIM (kg/cow) & 1.38 & 1.38 & 1.42 & 1.33 & 0.03 & * \\
Liveweight at drying off (kg) & 474 & 485 & 471 & 471 & 12 & n.s. \\
CS at drying off & 3.8 & 3.6 & 3.7 & 3.8 & 0.3 & n.s. \\
EFS (\$/ha) & 1568 & 1728 & 1793 & 1456 & 118 & * \\
\hline
\end{tabular}

${ }^{1} \mathrm{~ns}=$ no significant difference

$\dagger=$ a significant $(P<0.10)$ ryegrass $x$ clover interaction

* $=$ a significant $(P<0.05)$ ryegrass $x$ clover interaction

Table 3 2000/2001 season milk production, milk composition, cow liveweight and condition score (CS) at drying off, and Economic Farm Surplus (EFS; calculated assuming a payout of $\$ 4.00 / \mathrm{kg} \mathrm{MS}$ ) of the perennial ryegrass-white clover treatments. Figures are the means of the three replicate farmlets.

\begin{tabular}{|c|c|c|c|c|c|c|}
\hline \multirow{2}{*}{$\frac{\text { Ryegrass-white clover }}{\text { Days in milk (DIM) }}$} & \multicolumn{4}{|c|}{ 80R60C 98R60C 80R98C 98R98C } & \multirow{2}{*}{$\frac{\text { SED }}{2}$} & \multirow{2}{*}{$\begin{array}{l}1 \\
\text { n.s. }\end{array}$} \\
\hline & 244 & 242 & 238 & 242 & & \\
\hline Milk (kg/cow) & 4314 & 4413 & 4516 & 43 & 126 & n.s. \\
\hline concentration $(\%)$ & 4.33 & 4.26 & 4.21 & 4.2 & 0.13 & n.s. \\
\hline oncentration (\%) & 3.45 & 3.38 & 3.41 & 3.40 & 0.06 & n.s. \\
\hline Milksolids $(\mathrm{kg} / \mathrm{c}$ & 336 & 337 & 343 & 331 & 9 & n.s. \\
\hline Milksolids (kg/ha) & 1007 & 1009 & 1031 & 994 & 26 & n.s. \\
\hline Milksolids per DIM (kg/cow) & 1.37 & 1.39 & 1.44 & 1.37 & 0.03 & n.s. \\
\hline drying off $(\mathrm{kg})$ & 510 & 521 & 521 & 517 & 9 & n.s. \\
\hline $\mathrm{CS}$ at & 3.7 & 4.0 & 3.9 & 3.8 & 0.3 & n.s. \\
\hline EFS (\$/ha) & 2095 & 2119 & 2182 & 2043 & 110 & n.s. \\
\hline
\end{tabular}

${ }^{1} \mathrm{~ns}=$ no significant difference
mid-September and was probably related to the higher clover content in the $80 \mathrm{R} / 98 \mathrm{C}$ treatment (Eerens et al. 2001) and the consequent higher nutritive value of the pasture (Harris et al. 1997). The appearance of the trend after mid-September agrees with the finding that white clover has most effect on milk yield during summer-autumn, when the difference in nutritive value between clover and ryegrass is maximum (Rogers \& Robinson 1984).

Despite there still being a significant difference in clover content between the treatments in the 2000/ 2001 season (Eerens et al. 2001), this did not result the 2000/2001 sume comparatively high rainfall ove component of the pastures maintained its nutritive value at a higher level than would normally occur over summer-autumn and, therefore there was little difference in the total nutritive values for pasture on the respective treatments.

The decline in milksolids production on all treatments during periods of low rainfall, was a result of decreased pasture growth and therefore lower farm covers. This was observed in November-December in 1999/2000 (Figure 1a), and during February in the 2000/2001 season (Figure 1b). The decline in milksolids production over summer-autumn is a common feature of pastoral-based dairy farms in New Zealand and is usually due to declining pasture quality as ryegrass becomes reproductive and the proportion of dead material in the sward increases, and reduced pasture growth rates. It is interesting to note that the post-peak decline in milksolids production on all farmlets during the 2000/2001 season was less dramatic than in the 1999/2000 season (Figure 1). This was probably related to the comparatively higher nutritive value of the pasture in 2000/2001 summerautumn as outlined above, and the greater availability of pasture compared with the previous summer-autumn.

\section{Milk composition}

The trend in milksolids production was due solely to increased milk yield - there were no treatment effects on the concentrations of either milk fat or milk protein in either season (Tables 2 and 3). Harris et al. (1997) also reported that the 
Figure 1 Daily milksolids production per hectare during (A) 1999/2000 and (B) 2000/2001 for the 80R/60C ( $\bullet), 98 \mathrm{R} / 60 \mathrm{C}(\boldsymbol{\square}), 80 \mathrm{R} / 98 \mathrm{C}(\diamond)$ 98R/98C $(\square)$ treatments averaged over three replicate farmlets. The mean SED during 1999/2000 was $0.257 \mathrm{~kg} \mathrm{MS/ha/d}$. The mean SED during 2000/ 2001 was $0.208 \mathrm{~kg} \mathrm{MS} / \mathrm{ha} / \mathrm{d}$.
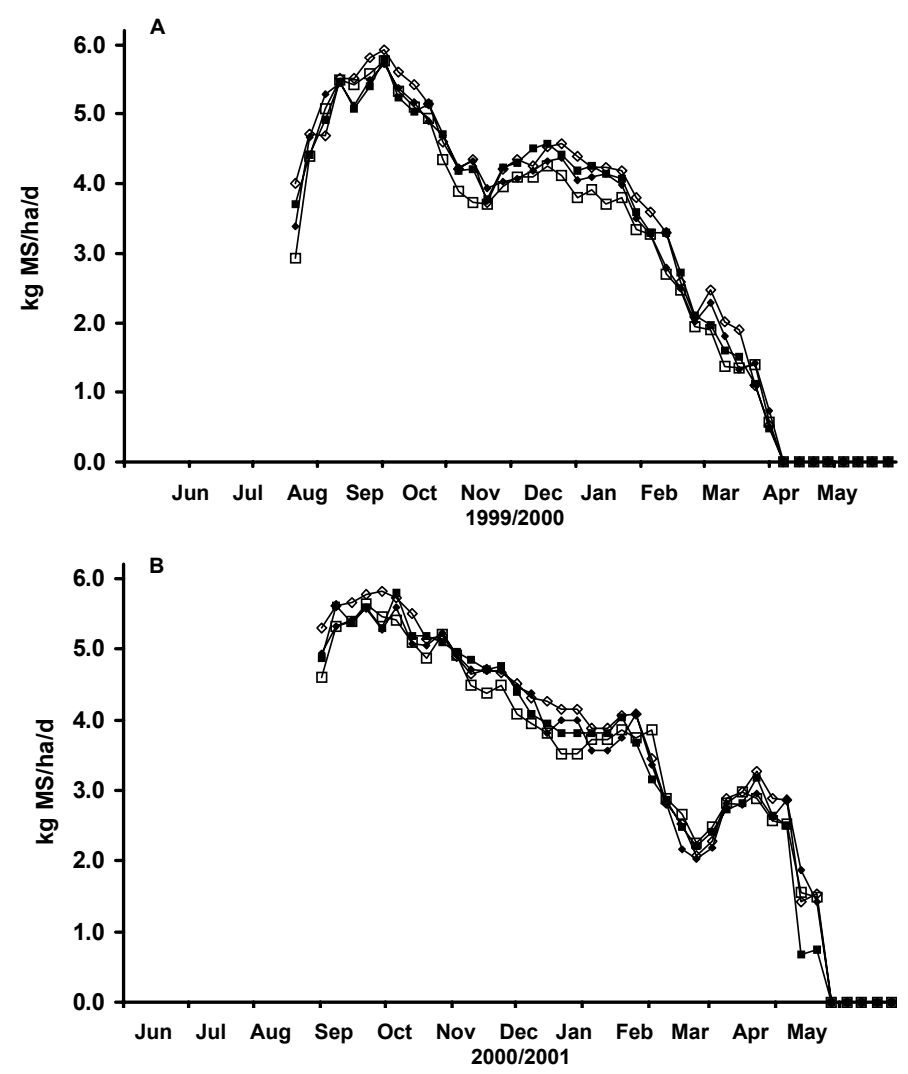

between treatments in some months. For example, pasture growth rates were slightly higher on the $98 \mathrm{R}$ treatments than on the $80 \mathrm{R}$ treatments during late autumn 1999/2000. This, however, had little effect on milksolids production since all cows were dried off at the beginning of April 2000. Late autumn pasture growth rates did not differ significantly between treatments in 2000/ 2001. In contrast, the $80 \mathrm{R}$ treatments appeared to have higher pasture growth in spring of both seasons. As a result, more pasture silage was made on the 80R farmlets, particularly the $80 \mathrm{R} / 98 \mathrm{C}$ treatment in 2000/2001, than on the $98 \mathrm{R}$ farmlets (Table 3 ). In both seasons, pasture silage supplementation began at the start of March following removal of cull cows from herds in an effort to maintain dry matter intakes of cows above the target $12 \mathrm{~kg} \mathrm{DM} /$ cow/day required for lactating cows, and to extend lactation. This was only possible, however, on farmlets where the amount of pasture silage made in late springearly summer exceeded the $140 \mathrm{~kg} \mathrm{DM} /$ cow set aside for feeding dry cows over winter. Differences between individual farmlets in the use of pasture silage supplement to extend lactation did delay drying off of cows on individual farmlets, but appeared to have no effect on the overall DIM or milksolids production comparisons between treatments (Tables 2 and 3 ).

proportion of perennial ryegrass or white clover in the diet had no effect on milk composition.

\section{Lactation length, drying off, condition scores and} liveweight of cows

Lactation length (DIM) was similar across all treatments (Tables 2 and 3) and was determined primarily by pasture availability on farms in late summer-early autumn. Thus, all herds milked longer in 2000/2001 when higher rainfall in summer-autumn resulted in higher pasture growth during summer-autumn than in $1999 / 2000$. In $2000 / 2001$ the last cows were dried off by 20 April compared with 1999/2000 when all cows were dry by 1 April.

There was no significant difference in total herbage accumulation between treatments in either season (Eerens et al. 2001) although analysis of pasture growth rate data within season showed some differences
After mid-March individual cows were dried off on the basis of low body condition score or low milk yield in accordance with the decision rules. Because drying-off decisions were made in order to maintain cow and heifer body condition score above predetermined targets, there were no significant differences between treatments in either cow condition score or liveweight at drying off (Tables 2 and 3).

In 1999/2000, pasture silage was supplemented to all herds following drying-off to assist with reaching pre-calving (mid-July 2000) cow condition score targets and the building up of farm pasture DM over winter. Cows on two farmlets (one 98R/60C farmlet and one 98R/98C farmlet) which had less than $140 \mathrm{~kg} \mathrm{DM} /$ cow silage conserved were fed bought-in maize silage ( $3 \mathrm{~kg} \mathrm{DM} / \mathrm{cow} / \mathrm{d}$ ) to supplement available pasture in order to reach body condition score targets. The cost of the maize silage $(\$ 0.20 / \mathrm{kg}$ DM; Dexcel Limited 
2000) was included in the EFS calculation for those farmlets. Between mid-May 2000 and early June 2000 some farmlets (two $80 \mathrm{R} / 60 \mathrm{C}$ farmlets, one $98 \mathrm{R} / 60 \mathrm{C}$ farmlet, one $80 \mathrm{R} / 98 \mathrm{C}$ farmlet and one $98 \mathrm{R} / 98 \mathrm{C}$ farmlet) had total herbage mass (average across whole farmlet) below the pre-determined minimum winter level $(1800 \mathrm{~kg} \mathrm{DM} / \mathrm{ha})$ due to poor pasture recovery following the summer-autumn drought, and the damage of pasture in several paddocks by black beetle (Heteronychus arator). These effects were related to soil type, not cultivar type, and resulted in cows on these farmlets being grazed-off for varying lengths of time until total herbage mass on the farmlets recovered. The cost of grazing-off $(\$ 1.40 /$ cow $/$ d; Dexcel Limited 2000) was included in the EFS calculations for $1999 / 2000$ and $2000 / 2001$. At the end of the 2000/2001 season adequate herbage masses on all farmlets meant that no further silage was fed between drying off and the end of the season, and no cows were grazed-off.

\section{Economic farm surplus}

Income arising from milksolids production $(\$ 4.00 / \mathrm{kg}$ MS; Dexcel Limited 2000) and the sale of unused pasture silage (sold at a price equivalent to the cost of making the silage, $\$ 0.20 / \mathrm{kg}$ DM; Dexcel Limited 2000) were the only sources of income to differ between farmlets in both seasons. Likewise, costs associated with the making and feeding of pasture silage, and the use of grazing-off or maize silage supplement, were the only expenses to differ across farmlets. While these sources of income and expenses differed between farmlets, ryegrass or clover cultivar age had no significant effect on EFS in either season (Tables 2 and 3). There was, however, a significant $(\mathrm{P}<0.05)$ ryegrass $\mathrm{x}$ clover interaction reflected as higher EFS on the $80 \mathrm{R} / 98 \mathrm{C}$ treatment than on the 98R/98C treatment during 1999/2000.

\section{Summary}

Over two complete seasons, this replicated dairy farm systems trial has demonstrated no major benefit in terms of either milksolids production or EFS to sowing different combinations of perennial ryegrass or white clover cultivars.. The slightly higher milksolids production and EFS measured on farmlets in 1999/2000 where 1980s ryegrasses had been sown in combination with 1998 clover cultivars, demonstrated the nutritional benefit of a higher clover content to lactating cows, particularly when ryegrass' growth rate and nutritional quality is suffering the effects of a dry summer-autumn. The higher clover content is assumed to have occurred because of greater tiller mortality rates in the 1980s ryegrasses, which had a lower initial endophyte status as indicated by pasture measurements collected during the trial (Eerens et al. 2001). The reduced tiller densities of the 1980s ryegrasses resulted in a more open pasture and therefore provided space for the 1998 clover cultivars to exploit. This farm systems trial will continue for two further seasons, which will provide data on persistence of the various cultivar types and any effects that this may have on farm profitability.

\section{ACKNOWLEDGEMENTS}

This research is fully funded by the New Zealand Dairy Board. John Caradus assisted with project management. Thank you to Shirley Nichols, Li Ouyang, Helen Simons, Liz Grayling and Elena Alley for the pasture measurements, and to staff at the Dexcel Scott Farm for management of the trial. Thank you also to Jim Lancaster and Barbara Dow for the collection and statistical analysis of cow data.

\section{REFERENCES}

Cosgrove, G.P.; Brougham, R.W. 1988. Pasture strategies for dairy beef production. Proceedings of the New Zealand Grassland Association 49: 57-62.

Dexcel Limited. 2000. 1999/2000 Economic survey of New Zealand dairy farmers. Dexcel Limited, Hamilton. 36pp.

Eerens, J.P.J.; Crush, J.R.; Woodward, S.L.; Macdonald, K.A.; Carter, W.A. 2001. Milksolids production from different combinations of perennial ryegrass and white clover cultivars: I. Trial design and pasture performance. Proceedings of the New Zealand Grassland Association 63: 91-96.

Harris, S.L.; Clark, D.A.; Auldist, M.J.; Waugh, C.D.; Laboyrie, P.G. 1997. Optimum white clover content for dairy pastures. Proceedings of the New Zealand Grassland Association 59: 29-33.

Laidlaw, A.S.; Reed, K.F.M. 1993. Plant improvement: the evaluation and extension process. Proceedings of the XVII International Grassland Congress: 385392.

Livestock Improvement. 2000. Dairy Statistics 19981999. Livestock Improvement Corporation Limited, Hamilton. 45 pp.

McCallum, D.A.; Thomson, N.A. 1994. The effect of perennial ryegrass cultivars on dairy animal performance. Proceedings of the New Zealand Society of Animal Production 54: 87-90.

Macdonald, K.A.; Penno, J.W. 1998. Management decision rules to optimise milksolids production on dairy farms. Proceedings of the New Zealand Society of Animal Production 58: 132-135. 
Moloney, S.C.; Hay, R.J.M.; Lancashire, J.A. 1988. The performance of Grasslands Kopu white clover on two dairy farms. Proceedings of the New Zealand Grassland Association 49: 97-100.

Penno, J.W.; Macdonald, K.A.; Bryant, A.M. 1996. The economics of No 2 dairy systems. Proceedings of the Ruakura Farmers' Conference 48: 11-19.

Rogers, G.; Robinson, I. 1984. Whole lactation production of cows grazing white clover or perennial ryegrass. pp. 148-149. In: Dairy Production Research Report. Department of Agriculture and Rural Affairs, Australia.
Thom, E.R.; Waugh, C.D.; McCabe, R.J. 1998. Growth and persistence of perennial and hybrid ryegrasses when grazed by dairy cows in the central Waikato region of New Zealand. New Zealand Journal of Agricultural Research 41: 477-486.

Woodward, S.L.; Caradus, J.R. 2000. Performance of white clover cultivars and breeding lines in rotationally grazed Waikato dairy pasture. New Zealand Journal of Agricultural Research 43: 323333. 